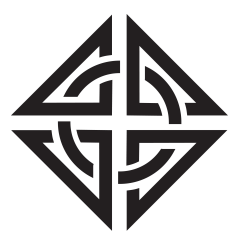

SCIENTIA

I RA N I C A
Sharif University of Technology

Scientia Iranica

Transactions C: Chemistry and Chemical Engineering

http://scientiairanica.sharif.edu

\title{
Methane adsorption on carbonaceous microporous materials prepared from cellulose and lignin: Equilibrium and kinetic studies
}

\author{
S. Pourebrahimi ${ }^{a}$, M. Kazemeini ${ }^{a, *}$, M. Zaroudi ${ }^{a}$, and H.R. Bozorgzadeh ${ }^{b}$ \\ a. Department of Chemical and Petroleum Engineering, Sharif University of Technology, Tehran, P.O. Box 11365-9465, Iran. \\ b. Gas Division, Research Institute of Petroleum Industry, West Blvd. of Azadi Sports Complex, Tehran, P.O. Box 18745-4163, \\ Iran.
}

Received 5 September 2017; received in revised form 2 April 2018; accepted 14 May 2018

\section{KEYWORDS \\ Activated carbon; Cellulose; \\ Lignin; \\ Methane storage; \\ Hydrothermal \\ pretreatment.}

\begin{abstract}
The present investigation highlights methane adsorption on synthesized Activated Carbons (ACs) based upon hydrothermally treated cellulose and lignin followed by chemical activation utilizing $\mathrm{ZnCl}_{2}$ as the activating agent. The influence of effective parameters such as hydrothermal pretreatment, precursor type, carbonization temperature, and impregnation ratio on the textural properties of synthesized materials as well as adsorption capacities of methane was examined. Thermal stability and decomposition procedures of cellulose and lignin were determined through the TGA technique while all prepared ACs were characterized via $\mathrm{N}_{2}$ adsorption-desorption analysis utilizing BET-BJH surface area measurement and Field Emission Scanning Electron Microscopy (FESEM). Amongst all prepared materials, the AC that was produced through impregnating hydrothermally treated cellulose with $\mathrm{ZnCl}_{2}$ with the ratio of 1 and carbonized at $600^{\circ} \mathrm{C}$ revealed improved surface and textural properties and enhanced methane storage. Furthermore, hydrothermal pretreatment provided micro-pore diameters ranging from 1.8 to $2.2 \mathrm{~nm}$. This resulted in $6.42 \mathrm{mmol} . \mathrm{g}^{-1}$ of methane adsorbed at $298 \mathrm{~K}$ and $3.65 \mathrm{MPa}$. In order to systematically understand behaviors of adsorbents in the process at hand, several kinetic and isotherm models were investigated.
\end{abstract}

(C) 2018 Sharif University of Technology. All rights reserved.

\section{Introduction}

Natural Gas (NG) is considered to be an important energy supply and a non-renewable source being inexpensive and abundantly available in the present world. The major problem of using the NG as fuel is believed

*. Corresponding author. Tel.: +982166165425;

Fax: +982166012983

E-mail addresses: sina.pourebrahimi@gmail.com (S.

Pourebrahimi); kazemini@sharif.edu (M. Kazemeini);

Maryzrd@gmail.com (M. Zaroudi); bozorgzadehhr@ripi.ir

(H.R. Bozorgzadeh)

doi: $10.24200 /$ sci. 2018.5131 .1114 to be its low energy density. The most common way of its storage for achieving high energy density is compression at high pressures (i.e., up to $20 \mathrm{MPa}$ ) while maintaining it in special vessels. Surely, this leads to high cost, which is considered to be the main disadvantage of this technique. On the other hand, a well-known alternative to this is the Adsorbed Natural Gas (ANG) technique. The advantage of utilizing this latter method is attributed to lowering the pressure (i.e., to 2-4 MPa), hence, reducing cost of storage [1]. In the ANG technique, a lightweight storage tank might be filled with a highly porous adsorbent using an inexpensive single-stage compressor.

A good carbon adsorbent for natural gas storage 
should possess: (i) high micro-porosity (i.e., pores with sizes below $2 \mathrm{~nm}$ ) for storage of small molecules like methane, (ii) low bulk density, to have high volumetric storage capacity, and (iii) high specific surface area with reactive-adsorptive sites for efficient adsorption [2]. Some adsorbents used for NG storage include zeolites [3], carbon nanotubes [4], and metalorganic frameworks $[5,6]$. In addition, in many cases, Activated Carbons (ACs) [7] demonstrate higher volumetric adsorption besides being simpler and having less expensive preparation procedures [8]. Extensive research has been carried out to explore applications of ACs for the NG storage purposes $[9,10]$.

Chemical activation with different agents including $\mathrm{KOH}, \mathrm{NaOH}, \mathrm{H}_{3} \mathrm{PO}_{4}$, and $\mathrm{K}_{2} \mathrm{CO}_{3}$ as well as physical activation with $\mathrm{CO}_{2}$ and steam has been applied for preparing the $\mathrm{AC}$ materials. By using chemical activation instead of the physical one, energy consumption and operating cost decrease; meanwhile, carbon yield increases and large micro-pore volume and surface area are obtained. Furthermore, the former activation leads to better porous structure than the physical one does [11]. Lignin and cellulose are carbon-rich and potentially available materials; hence, their transformation into ACs is considered to be economically feasible [12] while providing proper textural characteristics. Studies on the ACs produced from the lignin and cellulose indicate that carbon content of lignin is higher than that of cellulose; thus, the micropore volume of the $\mathrm{AC}$ produced from the former is higher than that from the latter [13]. On the other hand, the content of hydroxyl groups in the structure of cellulose is higher than that in lignin, causing creation of higher total pore volume and specific surface area in the structure of the produced AC [14]. In addition, utilizing hydrothermal carbonization (HTC) processes for producing $\mathrm{ACs}$ has recently been reported [15]. HTC, a wet thermal process, takes place at low temperatures $\left(180-300^{\circ} \mathrm{C}\right)$ in a closed system under relatively high pressure. During carbonization, a series of reactions occur, leading to generation of a carbonrich, high energy and density material referred to as hydrochar [16]. This results in incipient porosity and a special morphology, making it a suitable precursor for producing ACs [17]. Hence, the AC prepared in this manner has a well-defined micro-porous structure with high pore volume, specific surface area, and good yield.

Recently, a researcher produced a nano-structured activated carbon with a high specific surface area $\left(1700 \mathrm{~m}^{2} \cdot \mathrm{g}^{-1}\right)$, large pore volumes (composed of microand meso-pores equal to $\left.0.79 \mathrm{~cm}^{3} \cdot \mathrm{g}^{-1}\right)$, and an average pore diameter of $1 \mathrm{~nm}$ through hydrothermal pretreatment of hazelnut shells activated with the $\mathrm{KOH}$ solution [18]. In another work done, ACs were prepared from lignocellulosic materials by hydrothermal pretreatment followed by physical activation [19]. The resulting hydrochars had a weak porous structure with low-quality surface chemistry. However, activation with $\mathrm{CO}_{2}$ developed a micro-porous structure with a BET surface area of up to $438 \mathrm{~m}^{2} \cdot \mathrm{g}^{-1}$.

In the present study, samples of activated carbons were prepared from hydrothermally pretreated cellulose and lignin using $\mathrm{ZnCl}_{2}$ as an activating agent. Effects of the hydrothermal process and variable parameters such as impregnation ratio and carbonization temperature on textural and chemical-surface properties as well as methane storage capacities of the products were examined.

\section{Experimental}

\subsection{Materials}

The microcrystalline cellulose used in this work was obtained from the Merck Chemical Company (product\#102331 with molecular formula of $\left.\left(\mathrm{C}_{6} \mathrm{H}_{10} \mathrm{O}_{5}\right)_{n}\right)$. Elemental analysis of this white powder carried out by the vendor revealed $\mathrm{C}=44 \mathrm{wt} \%, \mathrm{H}=6 \mathrm{wt} \%$, and $\mathrm{O}=50 \mathrm{wt} \%$. The lignin with the molecular formula of $\left(\mathrm{C}_{9} \mathrm{H}_{10} \mathrm{O}_{2}\right)_{n}$ used in this work was a brown powder purchased from the Sigma-Aldrich Inc. (product\#471003 with low sulfonate content of 4wt\%). Elemental analysis of this powder performed also by the vendor showed $\mathrm{C}=61.4 \mathrm{wt} \%, \mathrm{H}=4.9 \mathrm{wt} \%$, ash $=0.7 \mathrm{wt} \%$, and $\mathrm{O}=29 \mathrm{wt} \%$. The activating agent of $\mathrm{ZnCl}_{2}$ (50 wt\%) was purchased from the Merck Chemical Company (product\#108816).

\subsection{Synthesis of activated carbons}

The hydrothermal pretreatment of raw cellulose and lignin was carried out through the following procedure. At each run, $10 \mathrm{~g}$ of raw material was mixed with $50 \mathrm{~mL}$ of deionized water and then, transferred into a stainless steel autoclave with removable internal cylindrical Teflon. Filling factor of the autoclave was about 0.83 . Then, the autoclave was placed in a furnace maintained at $250^{\circ} \mathrm{C}$ and equilibrated pressure of $\approx 2 \mathrm{MPa}$ (i.e., a mild set of hydrothermal condition) for $3 \mathrm{~h}$. Afterwards, this was left to quench at room temperature. The solid product of this treatment, referred to as the hydrochar, was separated from its surrounding liquid through filtration and washed thoroughly with distilled water. Finally, it was dried at $120^{\circ} \mathrm{C}$ for $6 \mathrm{~h}$ in an oven. Next, the dried hydrochar was impregnated with the 50 wt $\%$ solution of $\mathrm{ZnCl}_{2}$ activating agent at agent/precursor impregnation ratios of $0.5,1$, and 1.5. The impregnated samples were dried at $120^{\circ} \mathrm{C}$ for $24 \mathrm{~h}$. Then, carbonization was carried out at $500,600,700$, and $800^{\circ} \mathrm{C}$ under constant $\mathrm{N}_{2}$ flow of $250 \mathrm{~mL} / \mathrm{min}$. The heating rate applied was $4^{\circ} \mathrm{C} / \mathrm{min}$ and the carbonization time was set to $60 \mathrm{~min}$. All products were ultimately washed thoroughly with distilled water and $\mathrm{HCl}$. The resulting 
activated carbon was dried overnight. In addition, two samples were produced from cellulose and lignin without the aforementioned hydrothermal treatment.

\subsection{Characterization}

The thermal stability analysis of lignin and cellulose was performed through Thermo-Gravimetric Analysis (TGA) technique (Mettler Toledo 851 analyzer). Samples were heated from the room temperature to $800^{\circ} \mathrm{C}$ with a rate of $10^{\circ} \mathrm{C} / \mathrm{min}$ in a nitrogen atmosphere at a flow rate of $15 \mathrm{~mL} / \mathrm{min}$. The initial mass of every sample was $0.5 \mathrm{~g}$ at each run. The textural properties of the prepared ACs were characterized with a gas sorption analyzer (Micromeritics 2020 ASAP analyzer). BET surface area, pore volume, micro-pore volume, and average pore diameter were determined through nitrogen adsorption-desorption isotherms at $77 \mathrm{~K}$ (i.e., the BET-BJH surface area measurement). The FESEM images were obtained by a field emission scanning electron microscope (HITACHI S-4160) to explore the morphologies of the synthesized samples.

\section{4. $\mathrm{CH}_{4}$ adsorption measurements}

\subsubsection{Adsorption isotherms of $\mathrm{CH}_{4}$ on the samples}

In order to examine the $\mathrm{CH}_{4}$ adsorption capacities of the prepared adsorbents, an in-house-made volumetric apparatus was used under equilibrium conditions. The utilized rig had been provided in a previous publication by this research group [20].

\subsubsection{Obtaining experimental adsorption kinetic data} To investigate the time dependency of the $\mathrm{CH}_{4}$ adsorption upon the synthesized sorbents, pressure of the adsorption column was recorded at every $10 \mathrm{~s}$ interval until the adsorption system reached equilibrium. At that point, the pressure of the adsorption column became constant. Thus, through specifying the initial adsorption column pressure, one might calculate the adsorbed amounts of the $\mathrm{CH}_{4}$ at different time intervals, leading to kinetic evaluations of the system.

\subsubsection{Methane adsorption calculations}

To determine the amount of adsorbed methane, the dead volume measurement was crucial. It investigated the macro- and meso-pores through which methane adsorption might not take place and was performed by helium injection. The volumes of helium penetration into gas tank and the sample cell were assumed to be $V_{1}$ and $V_{2}$, respectively. The former (i.e., $V_{1}$ ) was calculated using the initial pressure in the gas tank $\left(P_{1}\right)$ and $V_{2}$ was the total volume calculated at the equilibrium pressure of the entire system $\left(P_{2}\right)$. The dead volume was thus obtained through Eq. (1):

$$
V_{\text {Void }}=V_{2}-V_{1}
$$

After helium injection and degassing at the temperature of $200^{\circ} \mathrm{C}$ in vacuum, methane injection was performed. In order to determine the mole numbers of methane, Eqs. (2) and (3) were utilized:

$$
\begin{aligned}
n_{M, i n i} & =\frac{P_{M, i n i} V}{Z_{M, i n i} R T}, \\
n_{M, e q} & =\frac{P_{M, e q} V}{Z_{M, e q} R T},
\end{aligned}
$$

in which $n_{M, i n i}$ and $n_{M, e q}$ represent the initial and equilibrium mole numbers of methane, respectively. Furthermore, $Z_{M, i n i}$ and $Z_{M, e q}$ represent the initial and equilibrium compressibility factors of methane before and after equilibrium, respectively. Thus, the total mole number of methane entered into the sample cell was determined through Eq. (4):

$$
n_{T}=n_{M, e q}-n_{M, i n i} .
$$

Finally, the total mole of adsorbed methane was calculated through Eq. (5):

$$
n_{\text {adsorbed }}=n_{T}-n_{\text {Void }}
$$

where, $n_{\text {Void }}$ is the amount of gas in the dead volume calculated from Eq. (6):

$$
n_{\text {Void }}=\frac{P_{M, e q} V_{\text {Void }}}{Z R T}
$$

Here, $P_{M, e q}$ is the equilibrium pressure of the system and $V_{\text {Void }}$ is the corresponding dead volume.

\section{Results and discussion}

\subsection{Characterization results}

\subsection{1. $\mathrm{N}_{2}$ adsorption-desorption isotherms of the samples}

In order to examine textural characteristics of the $\mathrm{AC}$ materials and effects of different synthesis parameters on them, nitrogen adsorption-desorption isotherms for all synthesized samples were determined; the results are presented in Figures 1 to 3 . According to obtained results in this work, most samples were of type I in the IUPAC classification, showing the microporous structure of the materials. Moreover, some isotherms exhibited hysteresis, i.e. they contained both micro- and meso-pores. Figure 1 (with logarithmic scale) exhibits the $\mathrm{N}_{2}$ isotherms obtained for four different samples at low relative pressures $\left(P / P_{0}<\right.$ 0.1 ). The isotherms of the materials produced with hydrothermal treatment followed a classical type-I behavior, suggesting possession of a permanent microporous structure. However, for samples synthesized with no hydrothermal treatment, type-IV behavior was observed. The group-1 ACs (i.e., with hydrothermal treatment) presented a sigmoidal shaped $\mathrm{N}_{2}$ adsorption behavior (see the logarithmic scale) corresponding to 


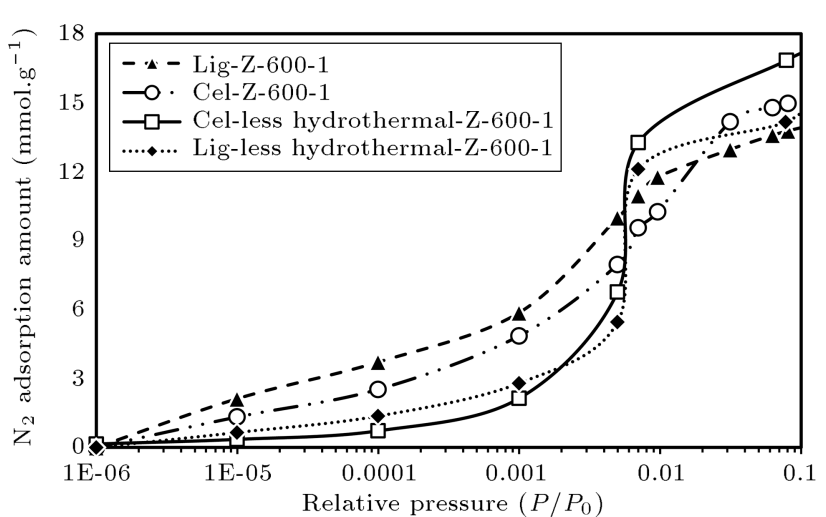

(a)

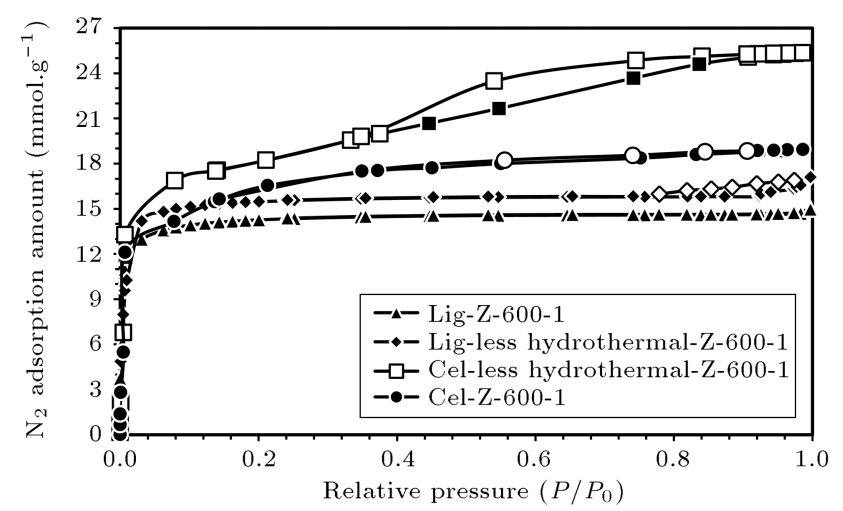

(b)

Figure 1. $\mathrm{N}_{2}$ adsorption-desorption isotherms of activated carbons produced from cellulose and lignin with and without hydrothermal treatment of the precursors. Logarithmic-scale (a) and linear-scale (b). Filled symbols: adsorption, and empty symbols: desorption.

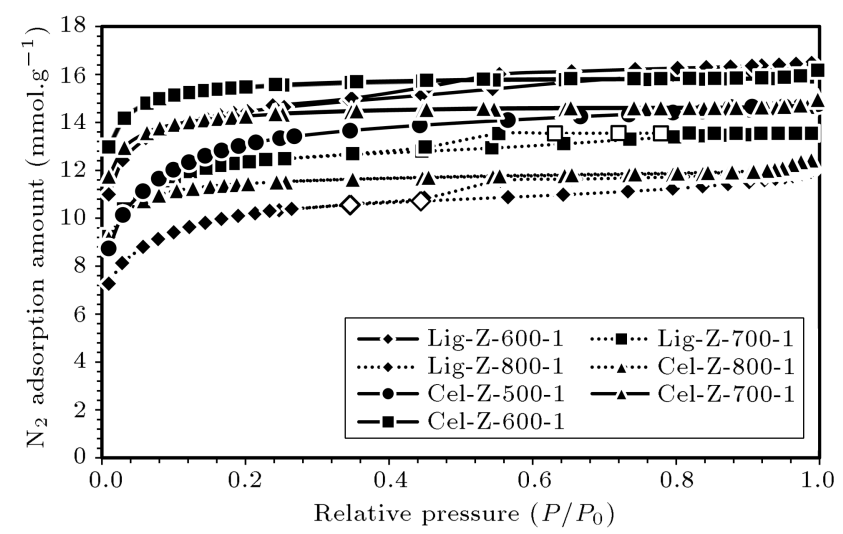

Figure 2. $\mathrm{N}_{2}$ adsorption-desorption isotherms of activated carbons produced from cellulose and lignin at different carbonization temperatures in the present research. Filled symbols: adsorption, empty symbols: desorption.

strong adsorption of $\mathrm{N}_{2}$ onto the pores. Consequently, pore fill-up was usually observed for smaller pore sizes. Moreover, the pressure range of micro-pore occupations increased with enhanced pore diameter of ACs in the group-2 materials (i.e., without hydrothermal treat-

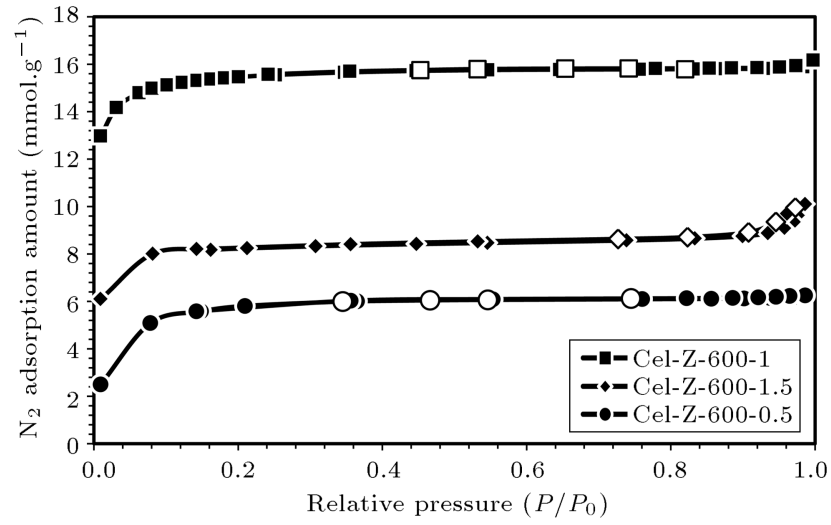

Figure 3. $\mathrm{N}_{2}$ adsorption-desorption isotherms of activated carbons produced from cellulose at $600^{\circ} \mathrm{C}$ with different impregnation ratios. Filled symbols: adsorption, and empty symbols: desorption.

ment). Thus, higher values of relative pressure (i.e., $\left.P / P_{0}\right)$ were observed for monolayer formation. Indeed, in group-2 ACs, significant sorption differences from group-1 were observed at higher relative pressures due to the multilayer formations or probably $2 \mathrm{D}$ condensations phenomenon.

\section{Effects of precursor type and carbonization temperature on the textural properties}

Textural characteristics of all synthesized samples are demonstrated in Table 1 . One can observe that cellulose-based materials produced higher BET surface areas and total pore volumes than lignin-based ones did at all corresponding carbonization temperatures. Presence of more hydroxyl groups in the structure of cellulose caused higher amounts of volatile gaseous compounds released. This left behind higher surface area and pore volume in structure of the final product. On the other hand, presence of more carbon in the structure of lignin led to producing higher extents of micro-pores (i.e., $V_{\text {micro }} / V_{\text {total }}$ ) in the related samples.

On the other hand, higher carbonization temperatures produced higher $V_{\text {micro }} / V_{\text {total }}$ and smaller average pore-diameters. However, for both cellulose and lignin-based materials, at carbonization temperatures above $700^{\circ} \mathrm{C}$, the pore diameter increased while the $V_{\text {micro }} / V_{\text {total }}$ ratio was lowered. At temperatures higher than $700^{\circ} \mathrm{C}$, widening of the pores probably caused further pore development, leading to lowering of the micro-pore volume. Similar results were also reported for brown coal-based activated carbons and ACs prepared from peach stone carbonized at 850 and $900^{\circ} \mathrm{C}$, respectively [21].

\section{Effect of hydrothermal treatment on the textural properties}

According to the results of Table 1, the samples produced from cellulose and lignin haydrochars revealed lower BET surface areas than those with no hydrother- 
Table 1. Textural characteristics of the prepared activated carbons from cellulous and lignin impregnated with different agent/precursor ratios and activated at different carbonization temperatures in this work.

\begin{tabular}{|c|c|c|c|c|c|c|c|c|}
\hline Sample ID & $\begin{array}{c}\text { Precursor } \\
\text { type }\end{array}$ & $\begin{array}{c}\text { Activating } \\
\text { agent }\end{array}$ & $\begin{array}{c}\text { Carbonization } \\
\text { temperature } \\
\left({ }^{\circ} \mathrm{C}\right)\end{array}$ & $\begin{array}{c}\text { Impregnation } \\
\text { ratio }\end{array}$ & $\begin{array}{c}D_{\text {ave }} \\
\text { (BJH) } \\
(\AA) \\
\end{array}$ & $\begin{array}{c}V_{\text {micro }} \\
\left(\mathrm{cm}^{3} / \mathrm{g}\right)\end{array}$ & $\begin{array}{c}V_{\text {total }} \\
\left(\mathrm{cm}^{3} / \mathrm{g}\right)\end{array}$ & $\begin{array}{c}S_{\mathrm{BET}} \\
\left(\mathrm{m}^{2} / \mathrm{g}\right)\end{array}$ \\
\hline Cel-Z-500-1 & Cellulose & $\mathrm{ZnCl}_{2}$ & 500 & 1 & 20.88 & 0.24 & 0.50 & 1011 \\
\hline Cel-Z-600-1 & Cellulose & $\mathrm{ZnCl}_{2}$ & 600 & 1 & 20.68 & 0.41 & 0.73 & 1293 \\
\hline Cel-Z-700-1 & Cellulose & $\mathrm{ZnCl}_{2}$ & 700 & 1 & 19.90 & 0.43 & 0.62 & 1091 \\
\hline Cel-Z-800-1 & Cellulose & $\mathrm{ZnCl}_{2}$ & 800 & 1 & 21.14 & 0.33 & 0.52 & 889 \\
\hline Lig-Z-600-1 & Lignin & $\mathrm{ZnCl}_{2}$ & 600 & 1 & 19.34 & 0.37 & 0.56 & 1100 \\
\hline Lig-Z-700-1 & Lignin & $\mathrm{ZnCl}_{2}$ & 700 & 1 & 18.95 & 0.32 & 0.46 & 956 \\
\hline Lig-Z-800-1 & Lignin & $\mathrm{ZnCl}_{2}$ & 800 & 1 & 19.63 & 0.28 & 0.41 & 782 \\
\hline Cel-Z-600-1.5 & Cellulose & $\mathrm{ZnCl}_{2}$ & 600 & 1.5 & 24.18 & - & 0.33 & 562 \\
\hline Cel-Z-600-0.5 & Cellulose & $\mathrm{ZnCl}_{2}$ & 600 & 0.5 & 22.10 & - & 0.27 & 383 \\
\hline $\begin{array}{c}\text { Cel-less } \\
\text { hydrothermal-Z-600-1 }\end{array}$ & Cellulose & $\mathrm{ZnCl}_{2}$ & 600 & 1 & 26.61 & 0.38 & 0.87 & 1371 \\
\hline $\begin{array}{c}\text { Lig-less } \\
\text { hydrothermal-Z-600-1 }\end{array}$ & Lignin & $\mathrm{ZnCl}_{2}$ & 600 & 1 & 24.43 & 0.31 & 0.65 & 1178 \\
\hline
\end{tabular}

mal treatment. Besides, the total pore volumes ( $\left.V_{\text {total }}\right)$ of the samples produced with no hydrothermal processing were higher than those of their hydrothermal counterpart. Nonetheless, their $V_{\text {micro }} / V_{\text {total }}$ ratios were rather low. This might be due to the sudden release of volatile functional groups such as $-\mathrm{OH}$, $-\mathrm{C}=\mathrm{O},-\mathrm{COOH}$, and volatile components existing in the cellulose's and lignin's internal structure, leaving larger pores behind mainly of meso type.

\section{Effect of impregnation ratio on the textural properties}

The optimum amount of $\mathrm{ZnCl}_{2}$ used as activating agent led to high methane adsorption in comparison with the virgin adsorbent. This was because of materials possessing higher BET surface areas and micro-pore volumes in addition to narrowing down the pore size distribution after incorporating the agent into the precursor. In the present study, the optimum impregnation ratio of $50 \mathrm{wt} \%$ activating agent to the precursor type was revealed to be 1 . These results were in agreement with those of the $\mathrm{N}_{2}$ adsorption-desorption isotherms for the samples presented in Figure 3.

\subsubsection{TGA and DTGA graphs of lignin and cellulose} The TG and DTG analyses of cellulose, lignin, and optimum sample (cellulose impregnated with $\mathrm{ZnCl}_{2}$ of impregnation ratio of 1 and carbonized at $600^{\circ} \mathrm{C}$ ) are presented in Figure 4(a)-(c). In the thermal decomposition profiles of cellulose and lignin (Figure 4(a) and (b)), a very distinct peak was observed at temperatures between 30 and $100^{\circ} \mathrm{C}$, which was related to the release of physisorbed water. However, a significant peak was observed at $300-400^{\circ} \mathrm{C}$ and attributed to the degradation of cellulose and lignin structures. In the current research, the DTGA peaks were at $366^{\circ} \mathrm{C}$ for the cellulose and $326^{\circ} \mathrm{C}$ for the lignin, both in acceptable agreement with previous work done by other researchers [22] reporting the DTGA peaks of $350^{\circ} \mathrm{C}$ for cellulose and $315^{\circ} \mathrm{C}$ for lignin. In this study, the final yield of lignin was higher than that of cellulose due to more volatility of the structure of cellulose. According to Figure 4(c), in the cel-Z-600-1 sample, the thermal decomposition occurred at several stages. From 50 to $400^{\circ} \mathrm{C}$, the weight loss was due to the release of water and decomposition of cellulose (happening at temperatures lower than $365^{\circ} \mathrm{C}$ ). It means that $\mathrm{ZnCl}_{2}$ proceeded to decompose the cellulose at low temperatures, hence limiting the char formation [23]. Then, a significant weight loss occurred at about $520^{\circ} \mathrm{C}$ in the main activation. This was due to the main porosity formed in the space left behind by the $\mathrm{ZnCl}_{2}$ species after being washed away with distilled water and acid, rather than volatilization of the material at its boiling point of $732^{\circ} \mathrm{C}$ [24].

\subsubsection{FESEM images of the prepared ACs}

Figure 5 presents the FESEM images of some selected AC samples synthesized in this research, revealing their morphologies. It indicates that the external surfaces of ACs prepared from cellulose and lignin activated with $\mathrm{ZnCl}_{2}$ were full of cavities resulting from 


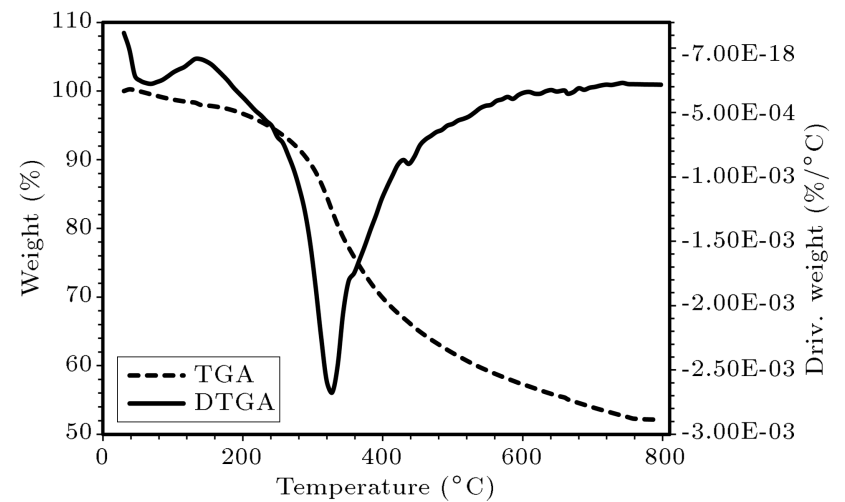

(a)

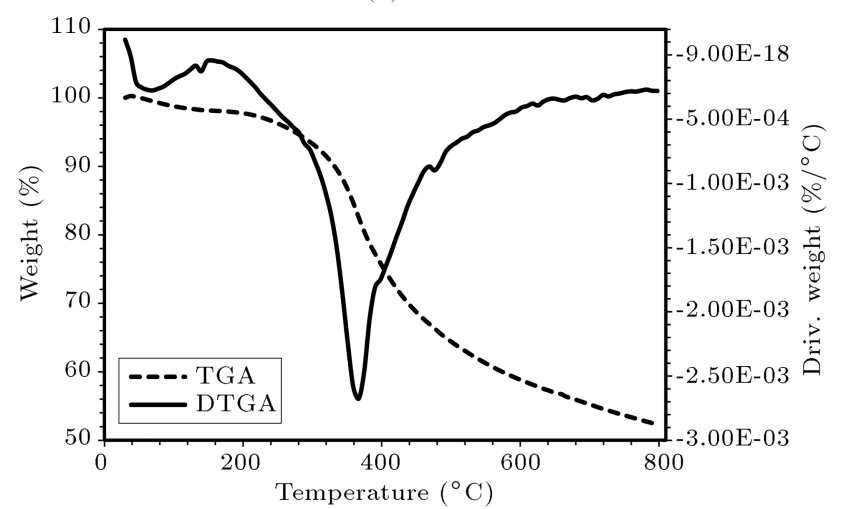

(b)

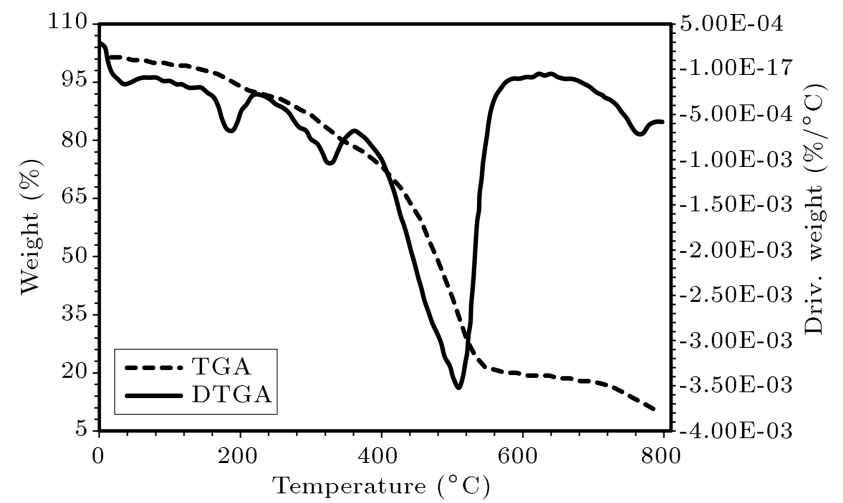

(c)

Figure 4. TGA and DTGA curves of (a) lignin, (b) cellulose, and (c) optimum sample (cel-Z-600-1) prepared in this research.

washing with distillated water and acid. Moreover, vaporization of volatile components existing in the internal structure of the samples such as $\mathrm{OH}, \mathrm{CO}$, and $\mathrm{CO}_{2}$ functional groups and the $\mathrm{Cl}_{2}$ gas molecules due to the $\mathrm{ZnCl}_{2}$ species led to this structure. These results were consistent with those obtained by other researchers [25].

\subsection{Methane adsorption experimental data}

\subsubsection{Effects of the precursor type}

This study revealed that, as a precursor for preparing ACs, cellulose led to materials with higher methane adsorption capacities than lignin did. In addition, the lignin-based samples possessed lower textural characteristics, such as BET surface area and $V_{\text {total }}$, than cellulose-based ones, leading to lower methane adsorption capacities. It is noteworthy that, in general, effective micro-pore size of the adsorbent should be three to six times higher than that of the adsorbate. Thus, for an adsorbate methane molecule with a diameter of $0.38 \mathrm{~nm}$, a material with pore diameters ranging from 1.2 to $2.2 \mathrm{~nm}$ is considered to be suitable as an adsorbent. Table 1 indicated that pore diameters of synthesized ACs in this research were well within this range.

\subsubsection{Hydrothermal treatment}

According to the results presented in Figures 6 and 7 , hydrothermal treatment affected methane adsorption capacities positively for both cellulose- and lignin-based materials. In other words, in case of cellulose-based sorbent, methane adsorption capacity was enhanced from 4.05 to $6.34 \mathrm{mmol} . \mathrm{g}^{-1}$ and, in case of lignin-based sorbent, it increased from 3.75 to $5.12 \mathrm{mmol} . \mathrm{g}^{-1}$ at $298 \mathrm{~K}$ and $3.8 \mathrm{MPa}$.

\subsubsection{Carbonization temperature}

Figures 8 and 9 provide information on the carbonization temperature effects on the methane adsorption.

It was noteworthy that creating the initial porosity and enriching the carbon content of the precursor were the purposes of carbonization. According to the results of the textural characteristics exhibited in Table $1,600^{\circ} \mathrm{C}$ was the optimum carbonization temperature at which such properties of both types of samples (i.e., lignin- and cellulose-based) were at their best positions, leading to the highest methane adsorption on cel-Z-600-1 and lig-Z-600-1 samples. In other words, the methane adsorption capacities of celZ-600-1 and lig-Z-600-1 species were determined to be 6.42 and $5.06 \mathrm{mmol} . \mathrm{g}^{-1}$ at $298 \mathrm{~K}$ and $3.65 \mathrm{MPa}$, respectively.

\subsubsection{Impregnation ratio}

Influence of the impregnation ratio on methane adsorption is displayed in Figure 10.

Based upon the results presented in Table 1, amongst all three synthesized cellulose-based samples, the "cel-Z-600-1" with impregnation ratio of 1 exhibited the optimum textural properties, including the highest specific surface area as well as relatively high micro- and total pore volumes. Moreover, this led to the highest methane adsorption capacities throughout the considered range of pressures at $298 \mathrm{~K}$ (please see Figure 10).

\subsection{5. $\mathrm{CH}_{4}$ equilibrium adsorption modeling}

Investigation into the adsorption thermodynamics of the studied systems was carried out through applying three different adsorption isotherms. The objective 


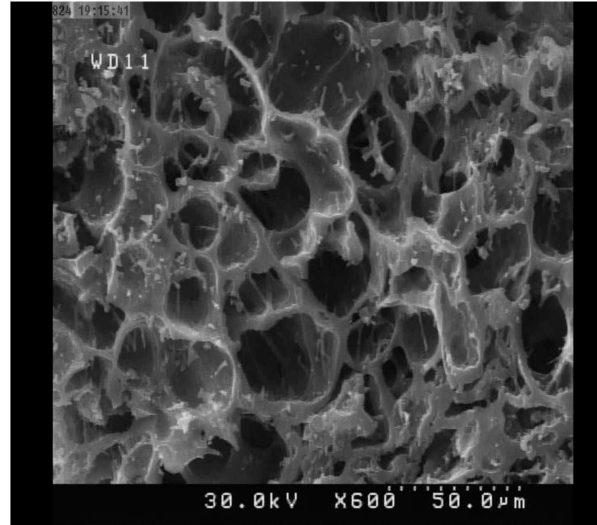

(a)

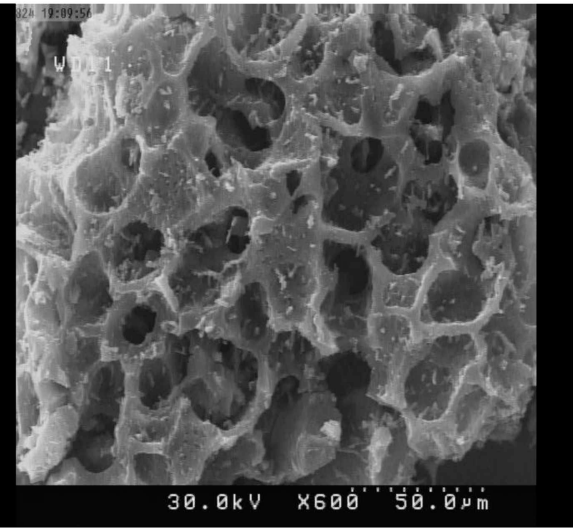

(b)

Figure 5. FESEM images of (a) cel-Z-600-1:1 and (b) lig-Z-600-1:1 synthesized in this work.

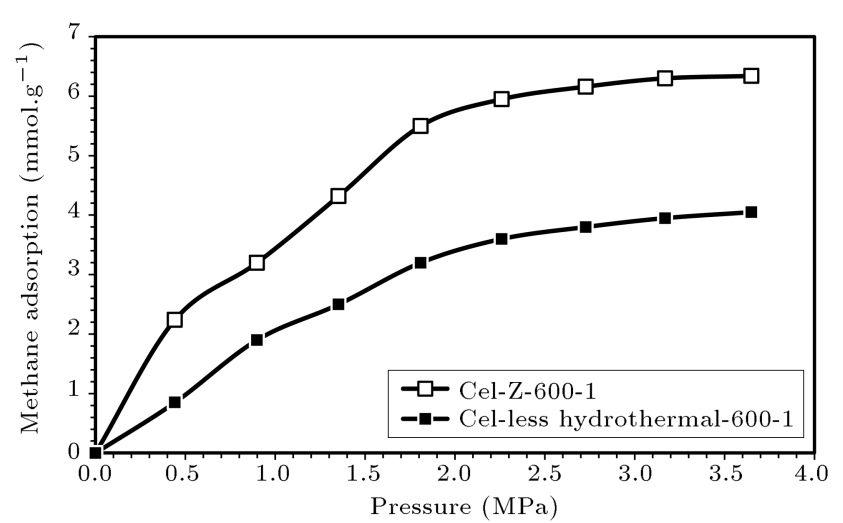

Figure 6. Adsorption isotherms of methane on cel-Z-600-1 and cel-less hydrothermal-Z-600-1 synthesized in this research.

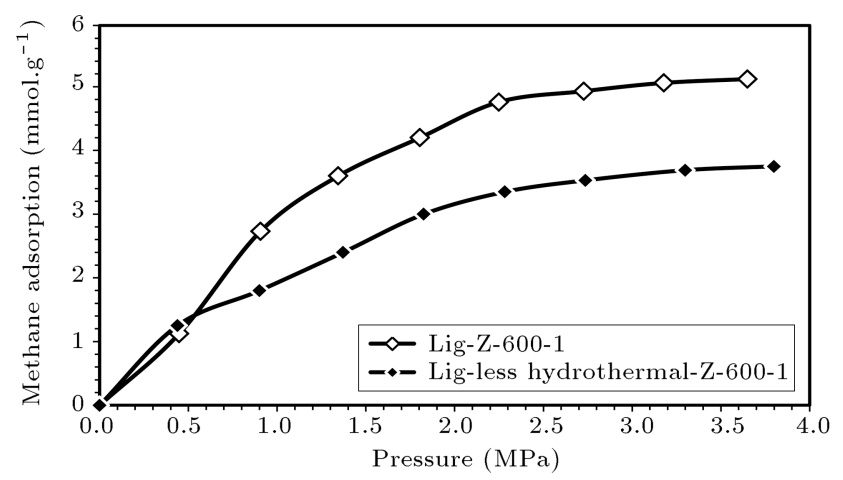

Figure 7. Adsorption isotherms of methane on

lig-Z-600-1 and lig-less hydrothermal-Z-600-1 synthesized in this research.

was to determine which model might describe the adsorption process more accurately. Langmuir (Eq. (7)), Freundlich (Eq. (8)), and Sips (Eq. (9)) equations were chosen to analyze the experimental data in this work. The following relations provided these models:

$$
q=\frac{q_{m} \cdot b \cdot P}{1+b \cdot P}
$$

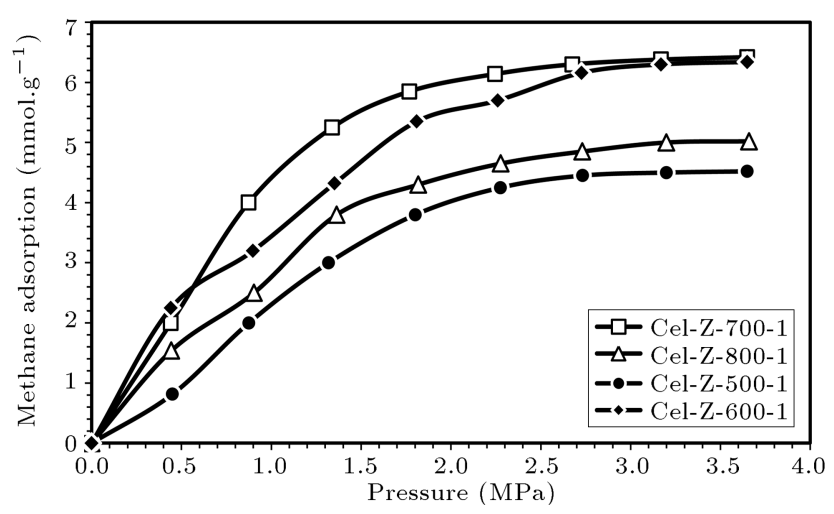

Figure 8. Adsorption isotherms of methane on prepared activated carbons from cellulose hydrochars at different carbonization temperatures of $500,600,700$, and $800^{\circ} \mathrm{C}$ with impregnation ratio of 1 made in this work.

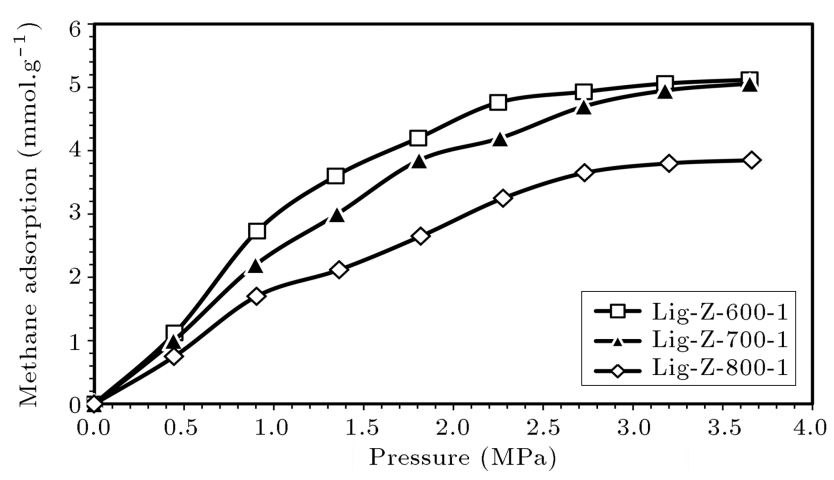

Figure 9. Adsorption isotherms of methane on prepared activated carbons from lignin hydrochars at different carbonization temperatures of 600,700 , and $800^{\circ} \mathrm{C}$ with impregnation ratio of 1 made in this work.

$$
\begin{aligned}
& q=K_{F} P^{1 / n} \\
& q=\frac{q_{m} \cdot(K . P)^{1 / n}}{1+(K . P)^{1 / n}},
\end{aligned}
$$

where $q_{m}\left(\mathrm{mmol}_{\mathrm{g}} \mathrm{g}^{-1}\right)$ is a Langmuir parameter related to the maximum adsorption capacity of methane 


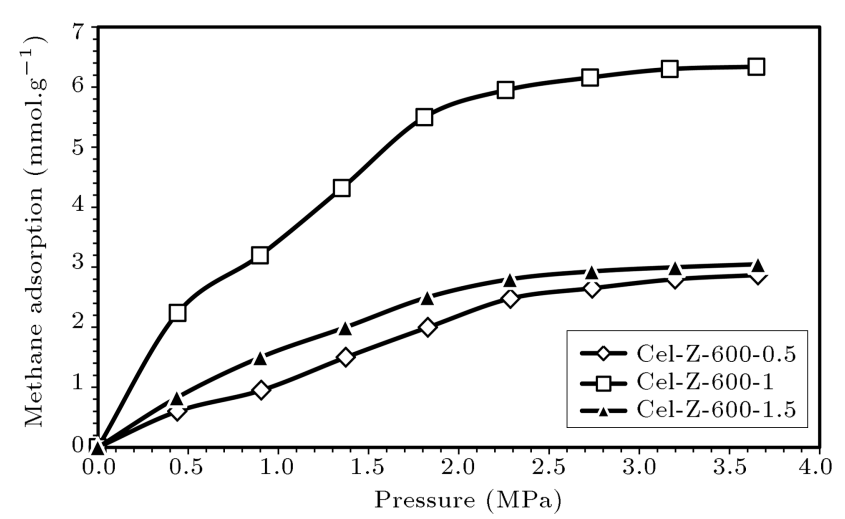

Figure 10. Adsorption isotherms of methane on activated carbons produced from cellulose hydrochars at $600^{\circ} \mathrm{C}$ with different impregnation ratios of $0.5,1$, and 1.5 prepared in this study.

on the prepared activated carbons and $b\left(\mathrm{MPa}^{-1}\right)$ is a Langmuir parameter related to the intensity of methane adsorption. $K_{F}\left(\mathrm{mmol} \cdot \mathrm{g}^{-1} \cdot \mathrm{MPa}^{-1 / n}\right)$ is the Freundlich constant and $n$ is surface heterogeneity parameter of the solid. The constant $K_{F}$ is an approximate indication of the adsorption capacity, while $1 / n$ is a function of the strength of adsorption [26]. However, $K_{F}$ and $n$ are characteristic parameters of the sorbent-sorbate system that should be determined through fitting with the experimental data. The model parameters with correlation coefficient, $R^{2}$, are represented in Table 2 and the simulated isotherms by the Langmuir, Freundlich, and Sips models are shown in Figure 11. Here, the data for the optimum cel-Z600-1 sample are demonstrated.

As shown in Table 2, for some samples, the $n$

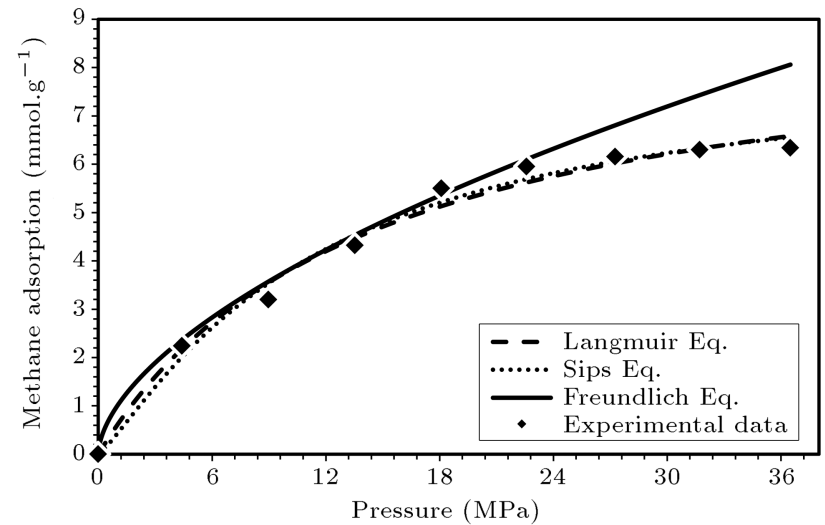

Figure 11. Comparison of theoretical adsorption isotherms using the Langmuir, Freundlich, and Sips models with experimental data for the cel-Z-600-1 sample in this research.

value was greater than 1 , indicating that the adsorption was cooperative and the surface should not be assumed homogeneous; both were consistent with results of other researchers [27]. In addition, the value of $q_{m}$, indicating the maximum adsorption capacity, was higher for the sample produced from cellulose than for that from lignin-hydrochars. This might be due to the higher BET surface areas and total pore volumes as well as acceptable micro-pore volumes of the samples prepared from cellulose. In addition, the value of $K_{F}$ (i.e., the intensity of adsorption) for the samples produced from cellulose and lignin hydrochars at $600^{\circ} \mathrm{C}$ with impregnation ratio of 1 was superior.

One can observe in Table 2 that Sips, as a combination of Langmuir and Freunlich models, ex-

Table 2. Isotherm constants of Langmuir, Freundlich, and Sips models for methane adsorption by activated carbons at $298 \mathrm{~K}$ according to the experimental data of the current paper.

\begin{tabular}{|c|c|c|c|c|c|c|c|c|c|c|c|c|c|}
\hline \multirow[t]{2}{*}{ Sample ID } & \multicolumn{4}{|c|}{ Langmuir } & \multicolumn{4}{|c|}{ Freundlich } & \multicolumn{5}{|c|}{ Sips } \\
\hline & $q_{m}$ & $b$ & $R^{2}$ & $r_{s}$ & $K_{F}$ & $n$ & $R^{2}$ & $r_{s}$ & $q_{m}$ & $b$ & $n$ & $R^{2}$ & $r_{s}$ \\
\hline Cel-Z-500-1 & 6.385 & 1.050 & 0.937 & 0.922 & 5.190 & 1.324 & 0.962 & 0.922 & 5.770 & 1.060 & 1.523 & 0.993 & 0.989 \\
\hline Cel-Z-600-1 & 9.124 & 0.710 & 0.976 & 0.934 & 5.800 & 1.005 & 0.987 & 0.958 & 8.137 & 0.890 & 1.213 & 0.990 & 0.987 \\
\hline Cel-Z-700-1 & 7.961 & 1.290 & 0.968 & 0.939 & 4.580 & 1.045 & 0.957 & 0.941 & 6.749 & 1.420 & 1.953 & 0.997 & 0.998 \\
\hline Cel-Z-800-1 & 5.858 & 0.960 & 0.914 & 0.911 & 4.950 & 1.474 & 0.953 & 0.936 & 5.752 & 0.840 & 1.362 & 0.986 & 0.975 \\
\hline Lig-Z-600-1 & 6.635 & 0.950 & 0.924 & 0.936 & 5.360 & 1.423 & 0.952 & 0.933 & 5.894 & 1.010 & 1.525 & 0.998 & 0.999 \\
\hline Lig-Z-700-1 & 6.578 & 0.820 & 0.905 & 0.928 & 5.160 & 1.481 & 0.962 & 0.968 & 7.691 & 0.530 & 1.072 & 0.997 & 0.992 \\
\hline Lig-Z-800-1 & 5.076 & 0.780 & 0.920 & 0.946 & 4.530 & 1.866 & 0.928 & 0. & 8.604 & 0.220 & 0.082 & 0.994 & 0.996 \\
\hline Cel-Z-600-0.5 & 3.599 & 0.890 & 0.861 & 0.935 & 4.600 & 3.536 & 0.785 & 0.897 & 5.194 & 0.360 & 0.965 & 0.995 & 0.999 \\
\hline Cel-Z-600-1.5 & 4.101 & 0.810 & 0.927 & 0.941 & 4.740 & 2.956 & 0.820 & 0.901 & 3.747 & 0.860 & 1.423 & 0.996 & 0.999 \\
\hline $\begin{array}{c}\text { Cel-less } \\
\text { hydrothermal-Z-600-1 }\end{array}$ & 5.089 & 0.960 & 0.881 & 0.905 & 4.930 & 1.959 & 0.914 & 0.938 & 5.406 & 0.700 & 1.242 & 0.996 & 0.998 \\
\hline $\begin{array}{c}\text { Lig-less } \\
\text { hydrothermal-Z-600-1 }\end{array}$ & 4.512 & 1.660 & 0.920 & 0.937 & 4.380 & 1.704 & 0.940 & 0.955 & 5.315 & 0.650 & 1.054 & 0.992 & 0.997 \\
\hline
\end{tabular}


plained the studied adsorption with a very satisfying $R^{2}(>0.99)$ in all experimental points. The Spearman's correlation coefficient $\left(r_{s}\right)$, which is generally used in assessing the global correlation and dispersion of its relative errors, was applied in the current work to evaluate statistical acceptance. Eq. (10) represents this error function:

$$
r_{s}=1-\frac{6 \sum_{i=1}^{n}\left(q_{\exp , i}-q_{c a l, i}\right)^{2}}{n(n-1)^{2}},
$$

where $n$ is the number of the experimental data, and $q_{\text {exp }}\left(\mathrm{mmol} . \mathrm{g}^{-1}\right)$ and $q_{\text {cal }}\left(\mathrm{mmol} . \mathrm{g}^{-1}\right)$ are the amounts of experimental and calculated adsorbed methane on the activated carbon surfaces through the adsorption isotherm model, respectively. It should be noted that as the value of $r_{s}$ becomes closer to 1 , the relative error of the equation is lowered; hence, it becomes more precise. Thus, based upon the values of error indicators presented in Table 2, the Sips model was chosen as the best one for describing adsorption of methane on the prepared activated carbons.

\subsection{6. $\mathrm{CH}_{4}$ adsorption kinetic modeling}

Kinetic investigations always provide significant information about the mechanism of a given process. Hence, to examine the mechanism of adsorption in this research, the $\mathrm{CH}_{4}$ adsorption on the optimum sample (cel-Z-600-1) was studied as a function of time. The obtained results are demonstrated in Figure 12.

As indicated in this figure, $\mathrm{CH}_{4}$ sorption was rather rapid during the first $30 \mathrm{~s}$ and, afterwards, it steadily continued to increase until equilibrium was achieved. Most probably, in the first 10-30 s, the $\mathrm{CH}_{4}$ molecules contacted external surfaces of the sorbents. Next, these molecules diffused into the AC's pores and were adsorbed on its internal surfaces. In other words, initially, the reactive-adsorptive sites on the external surfaces of the sorbent led to a rather intensive adsorption. Then, it was followed by a slow diffusion

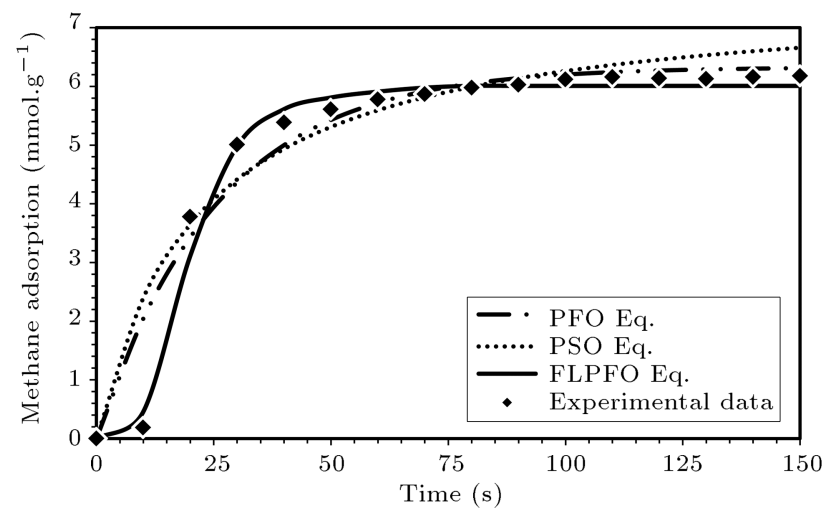

Figure 12. Effect of the contact time on the adsorption of $\mathrm{CH}_{4}$ at $4 \mathrm{MPa}$ and $298 \mathrm{~K}$ on the cel-Z-600-1 sample prepared in this work (the symbols show the experimental data). process. The experimental data were compared with several kinetic models including PFO (Pseudo First Order), PSO (Pseudo Second Order), and FL-PFO (Fractal-Like Pseudo First Order). The adjustable parameters with corresponding coefficient of determination, $R^{2}$, and Spearman's correlation coefficient, $r_{s}$, are exhibited in Table 4. The fitted kinetic models with experimental data are further demonstrated in Figure 12. Again, $\alpha$ is the parameter related to the heterogeneity of the adsorbent's surface and is often determined to be greater than 1, indicating the complexity of the adsorbent-adsorbate interactions. It should be noted that $k_{i}(i=1,2)$ was the kinetic constant of the aforementioned models due to the initial methane adsorption (e.g., during the first $30 \mathrm{~s}$ ) on the external surfaces of the sorbents until reaching an equilibrium plateau. In fact, greater values of $k_{i}$ might result in greater extent of initial adsorptions. As it can be observed in Table 3 and according to the more accurate kinetic model of FL-PFO (based upon the related values of $R^{2}$ and $r_{s}$ ), the values of $k_{i}$ were lowered due to decrease in the BET surface area of the materials considered (please see Table 1). Hence, it could be predicted that the sorbents possessing higher specific surface areas would lead to more pronounced initial adsorption. Figure 12 as well as the data provided in Table 3 show that the FL-PFO kinetic model theoretically best fitted the obtained experimental data due to its one more adjustable parameter than the other models utilized in this work.

\subsubsection{A comparison between the current and recent $\mathrm{CH}_{4}$ adsorptions}

Table 4 represents the $\mathrm{CH}_{4}$ adsorption capacity of some carbon-based adsorbents under a wide range of operating conditions of temperature and pressure. The data were prepared under different synthesis conditions of carbonization temperatures and types of activating agent. It became evident that, for the majority of cases, the carbonaceous adsorbents prepared in this work adsorbed higher amounts of $\mathrm{CH}_{4}$ than their openliterature counterparts under the same conditions. Satisfactory performances of the obtained optimum adsorbents in the current study (i.e., cel-Z-600-1 and lig-Z-600-1 samples) were due to the combination of three major factors, including the hydrothermal pretreatment, carbonization temperature, and ratio of a prevalent activating agent to the $\mathrm{AC}$ materials.

\section{Conclusion}

The hydrothermal pretreatment of cellulose and lignin species made highly micro-porous volumes and narrow pore diameter distribution of around $2 \mathrm{~nm}$ suitable for methane adsorption. Carbonizing at optimum temperature further allowed for development of micro- 
Table 3. Adjustable parameters to adsorption kinetic equations at $298 \mathrm{~K}$ studied in this research.

\begin{tabular}{|c|c|c|c|c|c|c|c|}
\hline Kinetic model & Adsorbent & $\begin{array}{c}q_{\text {cal }} \\
\left(\mathrm{mmol} \cdot \mathrm{g}^{-1}\right)\end{array}$ & $\begin{array}{c}k_{1} \\
\left(\min ^{-1}\right)\end{array}$ & $\begin{array}{c}k_{2} \\
\left(\min ^{-1}\right)\end{array}$ & $\alpha$ & $R^{2}$ & $\boldsymbol{r}_{s}$ \\
\hline \multirow{11}{*}{$\begin{array}{c}\text { Pseudo-first-order } \\
q_{t}=q_{e} \cdot\left(1-\exp \left(-k_{1} t\right)\right)\end{array}$} & Cel-Z-500-1 & 4.561 & 0.028 & - & - & 0.926 & 0.964 \\
\hline & Cel-Z-600-1 & 6.329 & 0.039 & - & - & 0.905 & 0.955 \\
\hline & Cel-Z-700-1 & 6.705 & 0.024 & - & - & 0.852 & 0.927 \\
\hline & Cel-Z-800-1 & 5.232 & 0.025 & - & - & 0.903 & 0.908 \\
\hline & Lig-Z-600-1 & 5.255 & 0.030 & - & - & 0.897 & 0.913 \\
\hline & Lig-Z-700-1 & 5.302 & 0.026 & - & - & 0.893 & 0.907 \\
\hline & Lig-Z-800-1 & 3.940 & 0.031 & - & - & 0.925 & 0.926 \\
\hline & Cel-Z-600-0.5 & 2.993 & 0.033 & - & - & 0.973 & 0.978 \\
\hline & Cel-Z-600-1.5 & 3.124 & 0.039 & - & - & 0.936 & 0.969 \\
\hline & Cel-less hydrothermal-Z-600-1 & 4.135 & 0.042 & - & - & 0.871 & 0.904 \\
\hline & Lig-less hydrothermal-Z-600-1 & 3.840 & 0.039 & - & - & 0.906 & 0.918 \\
\hline \multirow{11}{*}{$\begin{array}{l}\text { Pseudo-second-order } \\
\qquad q_{t}=\frac{k_{2} q_{e}^{2} t}{1+k_{2} q_{e} t}\end{array}$} & Cel-Z-500-1 & 5.931 & - & 0.005 & - & 0.882 & 0.897 \\
\hline & Cel-Z-600-1 & 7.629 & - & 0.006 & - & 0.784 & 0.846 \\
\hline & Cel-Z-700-1 & 8.499 & - & 0.003 & - & 0.758 & 0.820 \\
\hline & Cel-Z-800-1 & 6.770 & - & 0.003 & - & 0.871 & 0.869 \\
\hline & Lig-Z-600-1 & 6.641 & - & 0.004 & - & 0.825 & 0.886 \\
\hline & Lig-Z-700-1 & 6.805 & - & 0.004 & - & 0.845 & 0.871 \\
\hline & Lig-Z-800-1 & 4.982 & - & 0.006 & - & 0.898 & 0.819 \\
\hline & Cel-Z-600-0.5 & 3.577 & - & 0.010 & - & 0.931 & 0.944 \\
\hline & Cel-Z-600-1.5 & 3.796 & - & 0.011 & - & 0.894 & 0.965 \\
\hline & Cel-less hydrothermal-Z-600-1 & 4.935 & - & 0.009 & - & 0.836 & 0.865 \\
\hline & Lig-less hydrothermal-Z-600-1 & 5.025 & - & 0.008 & - & 0.789 & 0.859 \\
\hline \multirow{11}{*}{$\begin{array}{l}\text { Fractal like-pseudo-first-order } \\
\qquad q_{t}=q_{e} \cdot\left(1-\exp \left(-k_{1} t^{\alpha}\right)\right)\end{array}$} & Cel-Z-500-1 & 4.366 & 0.052 & - & 1.588 & 0.971 & 0.986 \\
\hline & Cel-Z-600-1 & 6.009 & 0.093 & - & 2.170 & 0.901 & 0.968 \\
\hline & Cel-Z-700-1 & 6.176 & 0.066 & - & 1.677 & 0.977 & 0.989 \\
\hline & Cel-Z-800-1 & 4.826 & 0.048 & - & 1.518 & 0.974 & 0.982 \\
\hline & Lig-Z-600-1 & 4.947 & 0.078 & - & 1.734 & 0.968 & 0.977 \\
\hline & Lig-Z-700-1 & 4.924 & 0.053 & - & 1.780 & 0.987 & 0.992 \\
\hline & Lig-Z-800-1 & 3.693 & 0.036 & - & 1.775 & 0.981 & 0.991 \\
\hline & Cel-Z-600-0.5 & 2.709 & 0.037 & - & 2.201 & 0.979 & 0.988 \\
\hline & Cel-Z-600-1.5 & 2.988 & 0.033 & - & 2.349 & 0.996 & 0.999 \\
\hline & Cel-less hydrothermal-Z-600-1 & 3.968 & 0.072 & - & 2.210 & 0.975 & 0.990 \\
\hline & Lig-less hydrothermal-Z-600-1 & 3.672 & 0.059 & - & 2.289 & 0.994 & 0.998 \\
\hline
\end{tabular}

pores on the internal structure of samples. Moreover, effects of $\mathrm{ZnCl}_{2}$ as the activating agent and influences of different parameters on the textural and structural properties as well as methane storage capacities of produced ACs were investigated. It was revealed that both carbonization temperature and impregnation ratio had great effects on textural quality of the final products. In addition, optimum temperature and impregnation ratio resulted in a product with a high BET surface area, micro-porous volume, and appropriate pore diameter size for methane adsorption. Moreover, the AC materials produced from cellulose, carbonized at $600^{\circ} \mathrm{C}$, and activated by $\mathrm{ZnCl}_{2}$ with the impregnation ratio of 1 provided the highest capacity for methane storage, which amounted to $6.42 \mathrm{mmol} . \mathrm{g}^{-1}$ due to the highest $V_{\text {micro }} / V_{\text {total }}$ ratio, suitable average pore diameter, and considerable specific surface area. Amongst several models considered, the Sips isotherm 
Table 4. $\mathrm{CH}_{4}$ adsorption capacities of some carbon-based adsorbents for comparison.

\begin{tabular}{|c|c|c|c|c|c|c|c|c|c|}
\hline \multirow{3}{*}{ Material } & \multirow{3}{*}{ Precursor } & \multicolumn{3}{|c|}{ Synthesis conditions } & \multicolumn{5}{|c|}{$\mathrm{CH}_{4}$ adsorption amount $\left(\mathrm{mmol} . \mathrm{g}^{-1}\right)$} \\
\hline & & \multirow[t]{2}{*}{$\begin{array}{c}\text { Hydrothermal } \\
\text { pretreatment }\end{array}$} & \multirow[t]{2}{*}{$\begin{array}{c}\text { Carbonization } \\
\text { temperature } \\
\left({ }^{\circ} \mathrm{C}\right)\end{array}$} & \multirow[t]{2}{*}{$\begin{array}{c}\text { Activating } \\
\text { agent }\end{array}$} & $\begin{array}{c}P=1 \\
\mathrm{MPa}\end{array}$ & $\begin{array}{c}P=2 \\
\mathrm{MPa}\end{array}$ & $\begin{array}{c}P=3 \\
\mathrm{MPa}\end{array}$ & $\begin{array}{c}P=4 \\
\mathrm{MPa}\end{array}$ & \multirow[t]{2}{*}{ Reference } \\
\hline & & & & & $T=298$ & $\mathrm{~K} T=298$ & $\mathrm{~K} T=298$ & $\mathrm{~K} T=298 \mathrm{~K}$ & \\
\hline $\mathrm{AC}$ & Sorghum & No & 300 & $\mathrm{H}_{3} \mathrm{PO}_{4}$ & 2.74 & 4.11 & 4.65 & 5.02 & {$[28]$} \\
\hline $\mathrm{AC}$ & Wheat & No & 300 & $\mathrm{H}_{3} \mathrm{PO}_{4}$ & 2.32 & 3.74 & 4.21 & 4.48 & {$[28]$} \\
\hline $\mathrm{AC}$ & Oil palm shell & No & 850 & $\begin{array}{c}\mathrm{CO}_{2} \\
\text { (physical } \\
\text { activation) }\end{array}$ & 2.85 & 4.23 & 4.77 & 5.16 & [29] \\
\hline $\mathrm{AC}$ & Oil palm shell & No & 850 & $\mathrm{ZnCl}_{2}$ & 2.69 & 4.05 & 4.54 & 4.96 & [29] \\
\hline $\mathrm{Ac}$ & Oil palm shell & No & 850 & $\mathrm{H}_{3} \mathrm{PO}_{4}$ & 2.81 & 4.14 & 4.70 & 5.08 & [29] \\
\hline $\mathrm{AC}$ & Corn cobs & No & 550 & $\mathrm{KOH}$ & 2.25 & 3.69 & 4.17 & 4.39 & [30] \\
\hline $\mathrm{AC}$ & Palm shell & No & 855 & $\mathrm{H}_{3} \mathrm{PO}_{4}$ & 2.95 & 4.38 & 4.86 & 5.25 & {$[31]$} \\
\hline $\mathrm{AC}$ & Coconut shell & No & No & $\mathrm{ZnCl}_{2}$ & 2.12 & 3.16 & 3.95 & 4.21 & {$[32]$} \\
\hline $\mathrm{AC}$ & Cellulose & No & 800 & $\begin{array}{c}\mathrm{CO}_{2} \\
\text { (physical } \\
\text { activation) }\end{array}$ & 3.12 & 4.89 & 5.32 & 5.68 & {$[33]$} \\
\hline $\mathrm{AC}$ & Sugarcane molasses & No & 800 & $\mathrm{KOH}$ & 4.26 & 5.89 & 7.96 & 8.24 & {$[34]$} \\
\hline $\mathrm{AC}$ & Cellulose & Yes & 600 & $\mathrm{ZnCl}_{2}$ & 3.15 & 5.13 & 6.18 & 6.45 & This work \\
\hline $\mathrm{AC}$ & Lignin & Yes & 600 & $\mathrm{ZnCl}_{2}$ & 2.95 & 4.42 & 4.96 & 5.16 & This work \\
\hline
\end{tabular}

satisfyingly fitted the determined experimental data. This led to the conclusion that the nature of the sorbents surfaces considered was heterogeneous. Then, the kinetics of $\mathrm{CH}_{4}$ adsorption on the prepared ACs were studied. Considering several kinetic models revealed that the FL-PFO equation satisfyingly described this system with a goodness of fit of above $97 \%$. In this regard, the adsorption constants demonstrated to be time dependent, which was considered as a consequence of the aforementioned surface heterogeneity of the synthesized materials.

\section{References}

1. Rios, R.B., Bastos-Neto, M., Amora Jr, M.R., Torres, A.E.B., Azevedo, D.C., and Cavalcante Jr, C.L. "Experimental analysis of the efficiency on charge/discharge cycles in natural gas storage by adsorption", Fuel, 90(1), pp. 113-119 (2011).

2. Prauchner, M.J. and Rodriguez-Reinoso, F. "Preparation of granular activated carbons for adsorption of natural gas", Microporous and Mesoporous Materials, 109(1-3), pp. 581-584 (2008).

3. Gholipour, F. and Mofarahi, M. "Adsorption equilibrium of methane and carbon dioxide on zeolite 13X: Experimental and thermodynamic modeling", The Journal of Supercritical Fluids, 111, pp. 47-54 (2016).

4. Yeganegi, S. and Gholampour, F. "Simulation of methane adsorption and diffusion in a carbon nanotube channel", Chemical Engineering Science, 140, pp. 62-70 (2016).
5. Shen, J., Sulkowski, J., Beckner, M., and Dailly, A. "Effects of textural and surface characteristics of metal-organic frameworks on the methane adsorption for natural gas vehicular application", Microporous and Mesoporous Materials, 212, pp. 80-90 (2015).

6. Blanco, A.A.G., Vallone, A.F., Korili, S.A., Gil, A., and Sapag, K. "A comparative study of several microporous materials to store methane by adsorption", Microporous and Mesoporous Materials, 224, pp. 323331 (2016).

7. Casco, M.E., Martinez-Escandell, M., Kaneko, K., Silvestre-Albero, J., and Rodríguez-Reinoso, F. "Very high methane uptake on activated carbons prepared from mesophase pitch: a compromise between microporosity and bulk density", Carbon, 93, pp. 11-21 (2015).

8. Zhang, T., Walawender, W.P., and Fan, L.T. "Grainbased activated carbons for natural gas storage", Bioresource Technology, 101(6), pp. 1983-1991 (2010).

9. Bagheri, N. and Abedi, J. "Adsorption of methane on corn cobs based activated carbon", Chemical Engineering Research and Design, 89(10), pp. 2038-2043 (2011).

10. Matos, J., Nahas, C., Rojas, L., and Rosales, M. "Synthesis and characterization of activated carbon from sawdust of Algarroba wood. 1. Physical activation and pyrolysis", Journal of Hazardous Materials, 196, pp. 360-369 (2011).

11. Khezami, L., Chetouani, A., Taouk, B., and Capart, R. "Production and characterisation of activated carbon from wood components in powder: cellulose, lignin, xylan", Powder Technology, 157(1-3), pp. 48-56 (2005). 
12. Cagnon, B., Py, X., Guillot, A., Stoeckli, F., and Chambat, G. "Contributions of hemicellulose, cellulose and lignin to the mass and the porous properties of chars and steam activated carbons from various lignocellulosic precursors", Bioresource Technology, 100(1), pp. 292-298 (2009).

13. Dastgheib, S.A. and Rockstraw, D.A. "Pecan shell activated carbon: synthesis, characterization, and application for the removal of copper from aqueous solution", Carbon, 39(12), pp. 1849-1855 (2001).

14. Sun, M. and Hong, L. "Impacts of the pendant functional groups of cellulose precursor on the generation of pore structures of activated carbons", Carbon, 49(7), pp. 2173-2180 (2011).

15. Sevilla, M. and Fuertes, A.B. "The production of carbon materials by hydrothermal carbonization of cellulose", Carbon, 47(9), pp. 2281-2289 (2009).

16. Roman, S., Nabais, J.V., Ledesma, B., González, J.F., Laginhas, C., and Titirici, M.M. "Production of low-cost adsorbents with tunable surface chemistry by conjunction of hydrothermal carbonization and activation processes", Microporous and Mesoporous Materials, 165, pp. 127-133 (2013).

17. Lu, X., Pellechia, P.J., Flora, J.R., and Berge, N.D. "Influence of reaction time and temperature on product formation and characteristics associated with the hydrothermal carbonization of cellulose", Bioresource Technology, 138, pp. 180-190 (2013).

18. Demiral, H., Demiral, I., Tümsek, F., and Karabacakoğlu, B. "Pore structure of activated carbon prepared from hazelnut bagasse by chemical activation", Surface and Interface Analysis, 40(3-4), pp. 616619 (2008).

19. Rodriguez-Reinoso, F. and Molina-Sabio, M. "Activated carbons from lignocellulosic materials by chemical and/or physical activation: an overview", Carbon, 30(7), pp. 1111-1118 (1992).

20. Pourebrahimi, S., Kazemeini, M., Babakhani, E.G., and Taheri, A. "Removal of the $\mathrm{CO}_{2}$ from flue gas utilizing hybrid composite adsorbent MIL-53 (Al)/GNP metal-organic framework", Microporous and Mesoporous Materials, 218, pp. 144-152 (2015).

21. Carrott, P.J.M. and Carrott, M.R. "Lignin-from natural adsorbent to activated carbon: a review", Bioresource Technology, 98(12), pp. 2301-2312 (2007).

22. Hu, J., Shen, D., Wu, S., Zhang, H., and Xiao, R. "Effect of temperature on structure evolution in char from hydrothermal degradation of lignin", Journal of Analytical and Applied Pyrolysis, 106, pp. 118-124 (2014).

23. Uçar, S., Erdem, M., Tay, T., and Karagöz, S. "Preparation and characterization of activated carbon produced from pomegranate seeds by $\mathrm{ZnCl}_{2}$ activation", Applied Surface Science, 255(21), pp. 8890-8896 (2009).

24. Salame, I.I. and Bandosz, T.J. "Role of surface chemistry in adsorption of phenol on activated carbons",
Journal of Colloid and Interface Science, 264(2), pp. 307-312 (2003).

25. Caturla, F., Molina-Sabio, M., and Rodriguez-Reinoso, F. "Preparation of activated carbon by chemical activation with $\mathrm{ZnCl}_{2}$ ", Carbon, 29(7), pp. 999-1007 (1991).

26. Pourebrahimi, S., Kazemeini, M., and Vafajoo, L. "Embedding graphene nanoplates into MIL-101 (Cr) pores: Synthesis, characterization, and $\mathrm{CO}_{2}$ adsorption studies", Industrial \& Engineering Chemistry Research, 56(14), pp. 3895-3904 (2017).

27. Arami-Niya, A., Daud, W.M.A.W., and Mjalli, F.S. "Comparative study of the textural characteristics of oil palm shell activated carbon produced by chemical and physical activation for methane adsorption", Chemical Engineering Research and Design, 89(6), pp. 657-664 (2011).

28. Diao, Y., Walawender, W.P., and Fan, L.T. "Activated carbons prepared from phosphoric acid activation of grain sorghum", Bioresource Technology, 81(1), pp. 45-52 (2002).

29. Arami-Niya, A., Daud, W.M.A.W., Mjalli, F.S., Abnisa, F., and Shafeeyan, M.S. "Production of microporous palm shell based activated carbon for methane adsorption: modeling and optimization using response surface methodology", Chemical Engineering Research and Design, 90(6), pp. 776-784 (2012).

30. Bagheri, N. and Abedi, J. "Preparation of high surface area activated carbon from corn by chemical activation using potassium hydroxide", Chemical Engineering Research and Design, 87(8), pp. 1059-1064 (2009).

31. Guo, J. and Lua, A.C. "Surface functional groups on oil-palm-shell adsorbents prepared by $\mathrm{H}_{3} \mathrm{PO}_{4}$ and $\mathrm{KOH}$ activation and their effects on adsorptive capacity", Chemical Engineering Research and Design, 81(5), pp. 585-590 (2003).

32. Azevedo, D.C., Araujo, J.C.S., Bastos-Neto, M., Torres, A.E.B., Jaguaribe, E.F., and Cavalcante, C.L. "Microporous activated carbon prepared from coconut shells using chemical activation with zinc chloride", Microporous and Mesoporous Materials, 100(1-3), pp. 361-364 (2007).

33. Himeno, S., Komatsu, T., and Fujita, S. "Highpressure adsorption equilibria of methane and carbon dioxide on several activated carbons", Journal of Chemical \& Engineering Data, 50(2), pp. 369-376 (2005).

34. Sreńscek-Nazzal, J., Kamińska, W., Michalkiewicz, B., and Koren, Z.C. "Production, characterization and methane storage potential of $\mathrm{KOH}$-activated carbon from sugarcane molasses", Industrial Crops and Products, 47, pp. 153-159 (2013).

\section{Biographies}

Sina Pourebrahimi received his BSc degree in Chemical Engineering from Isfahan University of Technology, 
Isfahan, Iran, in 2012, and his MSc degree in Chemical Engineering from Sharif University of Technology, Tehran, Iran, in 2014. He performed his MSc thesis under the supervision of Prof. Mohammad Kazemeini. His research interests include adsorption, catalysis, and materials chemistry.

Mohammad Kazemeini is currently Professor of Chemical and Petroleum Engineering at Sharif University of Technology, Tehran, Iran. His current research interests include nanocatalysts (mostly CNT and CNF as well as carbonecous based) preparation, characterization and evaluation in the field of chemical engineering, and petroleum refining.

Maryam Zaroudi received her BSc degree in Chemical Engineering from Amirkabir University of Tech- nology, Tehran, Iran, in 2012, and her MSc degree in the same field from Sharif University of Technology, Tehran, Iran, in 2014. She investigated methane adsorption on ACs in Research Institute of Petroleum Industry, Tehran, Iran. Her research mainly focuses upon gas adsorption and separation.

Hamid Reza Bozorgzadeh has been working at RIPI (Research Institute of Petroleum Industry) as a Faculty Member since 2002. He received his BSc degree from the Technische Fachhoch schule (TFH) of Berlin, Germany, in 1997, and PhD in Physical Chemistry from the University-Potsdamm, Germany, in 2002. His main research interests include synthesis of heterogeneous catalysts, adsorbents, their characterization, and determination of catalytic reaction mechanisms as well as adsorption processes. 